\title{
KAREL DEŽMAN IS NOT FORGOTTEN
}

When writing about Karel Dežman in the journal Acta carsologica 35/1, Stanislav Južnič ${ }^{1}$ noted that Dežman's work was almost forgotten, even though he had been one of the leading nature historians of his time. In the abstract, Južnič underlined:

»His scientific works are not very well known because he did not follow the political line of the official Slovenian national representatives. «

In the summary, on the other hand, the author wrote:

»With the use of published works and manuscripts we can thus present, for the first time in greater detail, Dežman's great knowledge that extended even into mathematical and astronomical sciences."

Karel Dežman, however, is and has not been forgotten, considering that much has been written about him in the last decade and that particularly his botanical activities have been covered relatively well.

This is what was written about Dežman's link with the botanist Valentin Plemel, his friend and grammar school classmate, by Nada Praprotnik ${ }^{2}$ who presented his botanical activities at the symposium Flora of Slovenia $2000^{3}$ and eventually published her supplemented and extended paper in the journal Argo ${ }^{4}$. About his work carried out at Ljubljansko barje, she wrote an article published in Narava Slovenije ${ }^{5}$.

Karel Dežman worked during the botanical quietude in the period between Franc Hladnik and Alfonz Paulin. As a botanist, he began to engage in new spheres and soon surpassed, especially with his phytogeographical contributions, till then mostly floristic orientation of our nature scientists. He wrote much about the flora of Ljubljansko barje, was the first to call attention to the newly introduced (adventive) species in our country, and listed the lowest lying localities of the Alpine flora in Carniola. His herbarium collection is kept by the Slo-

\footnotetext{
${ }^{1}$ Južnič, S., 2006: Karst research in the 19th century - Karel Dežman's (1821-1889) work. - Acta carsologica 35/1, pp.139148, Ljubljana.

${ }^{2}$ Praprotnik, N., 1992: Botanik Valentin Plemel in njegov herbarij. - Scopolia 27, pp. 1-42. Ljubljana.

${ }^{3}$ Praprotnik, N., 2000: Botanično delovanje Karla Dežmana. - Zbornik izvlečkov referatov simpozija Flora Slovenije 2000, p. 28, Ljubljana.

${ }^{4}$ Praprotnik, N., 2001: Karel Dežman in njegovo botanično delovanje. - Argo 44/2, pp. 14-20, Ljubljana.

${ }^{5}$ Praprotnik, N., 2001: Iz zgodovine botaničnih raziskav Ljubljanskega barja: Karel Dežman (1821-1889). - In: Narava Slovenije, Ljubljansko barje in Iška (Ed.: A. Gogala), pp. 27-28, Ljubljana.
}

vene Museum of Natural History. At the beginning of his professional career, Dežman was engaged largely in botanical research, and it is his very botanical work that is presented fairly comprehensively and suitably evaluated.

In his life, Dežman was highly versatile, and as he was a leading personality in several spheres, it is difficult to present him in full. With his scientific criticalness he had a strong and favourable effect on domestic professional public and contributed a great deal primarily to the academic development of the Museum, for which he worked from 1852 till his death in 1889. Thanks to him, a new building was erected in 1888 for the Carniolan Provincial Museum, which is still home to two national institutions: the Slovene Museum of Natural History and the National Museum of Slovenia. Dežman's museal work has never been suppressed, as he is correctly cited in all historical surveys. It is true, however, that his museal merits have no doubt been insufficiently underlined!

As a member of the Ljubljana Street Naming Committee, Prof Dr Tone Wraber proposed (during his mandate from 1991 to1995) one of the streets (perhaps on the edge of Ljubljansko barje) to be named after Dežman and thus "to confirm the return of a lost son at the time when Slovenia acquired its independence«. Unfortunately, his endeavours proved unsuccessful.

Karel Dežman plays a discernible role also in the work by Dragan Matić ${ }^{6}$ as »a herald of the Germans in Carniola« from 1861 onwards.

In Južnič’s article, the portrait of Karl Dežman was published as well (with the painting's basic details missing). It was made by Filip Fröhlich around 1865 and is kept by the National Museum of Slovenia.

At the end, let us quote the following conciliatory words published by Bleiweis's Novice ${ }^{7}$ after Dežman's death:

"If we are now to make a final estimate of Deschmann's work, it is difficult to judge whether his bantering made more harm than good for the mental development of the Slovenian nation. Deschmann's merits for the provincial museum have been acknowledged both by his followers and adversaries, and this is why we, too, are calling out at his grave: »Let him rest in peace!«

Nada Praprotnik

\footnotetext{
${ }^{6}$ Matič, D., 2002: Nemci v Ljubljani 1861-1918. Ljubljana.

${ }^{7}$ Novice, 1889, p. 87. Ljubljana.
} 